\title{
Collagen production from chicken keel bone using acid and enzymatic treatment at a temperature of $30^{\circ} \mathrm{C}$
}

\author{
Ana Rita Ribeiro de Araújo CORDEIRO ${ }^{*}$ (D), Taliana Kênia Alencar BEZERRA ${ }^{1}$, Angela Lima Menêses de QUEIROZ ${ }^{1}$, \\ Mércia de Sousa GALVÃO${ }^{1}$, Monica Tejo CAVALCANTI ${ }^{2}$, Maria Teresa Bertoldo PACHECO ${ }^{3}$, Marta Suely MADRUGA ${ }^{1}$
}

\begin{abstract}
The aim of this study was to investigate the effect of acid pretreatment, temperature and enzyme concentration on the acid-enzymatic extraction of soluble collagen from chicken keel bone cartilage. A chemical composition analysis and protein profile characterization of this slaughter by-product were also conducted. The cartilages were extracted with $0.5 \mathrm{~mol} / \mathrm{L}$ of acetic, lactic and citric acids for 24, 48 and 72 hours. Subsequently, optimization with a $2^{2}$ factorial design was performed with three replications at the central point for a total of 7 experiments; the analyzed response was the collagen content of the obtained isolates. The cartilage under study has a high protein content $(90.27 \%$ dry basis $)$ consisting of approximately $35.7 \%$ collagen and is a source of essential and predominantly hydrophobic amino acids. Pretreatment with acetic acid for 24 hours led to greater extraction potential and consequently, a better collagen yield (30.12\%). The electrophoretic profile of the obtained collagens revealed the existence of an a 1 chain, indicating that this collagen was type II. Statistical analysis demonstrated that the acid-enzymatic procedure favored a temperature of $30^{\circ} \mathrm{C}$.
\end{abstract}

Keywords: acid pretreatment; by-product; chicken keel bone cartilage; pepsin-soluble collagen; temperature.

Practical Application: The collagen obtained from chicken keel bone cartilage is a high value-added product that presents several biochemical and biomedical applications, as well as being an immunologically safe material for food applications. Obtaining enzymatic hydrolysates from keel bone cartilage appears as a pertinent possibility to obtain collagen and isolated peptides that may reveal biological activities. Therefore, high nutritional and high economical value products may appear as aggregators to the production of broilers.

\section{Introduction}

During the slaughter of chickens, the carcass is considered the main commercial object, and the other parts of the animal are classified as by-products (Lafarga \& Hayes, 2014). These by-products may represent approximately $37 \%$ of the total live weight of the animal and consist of cartilage, bones, wattle, comb, feet, head, feathers, adipose tissues and internal organs (Toldrá et al., 2012).

During processing of the chicken carcass, the filleting step generates a by-product known as keel bone cartilage, which is defined as a flexible cartilage that connects the breast muscle of the chicken to the tip of the sternum. This cartilage is discarded from the carcass after removal of the breast fillets (Losso \& Ogawa, 2014). This cartilage is rich in collagen, which is a high added value product with possible biochemical and biomedical applications (Wang et al., 2017).

The collagen that makes up connective tissue is usually extracted by dissolving the tissue in organic acid to obtain so-called "acid-soluble collagen". However, the native form of collagen remains in this product and requires the addition of an enzyme, usually pepsin, to degrade the covalent cross-links in the telopeptide regions and obtain the "pepsin-soluble collagen" fraction. The use of pepsin allows the peptide-binding regions to be broken without damaging the integrity of the triple helix, which provides a greater yield when collagen is extracted with controlled pepsin digestion (Liu et al., 2012).

The composition of collagen from the cartilage of aquatic and terrestrial animals has been the object of study by researchers (Gómez-Guillén et al., 2011; Simões et al., 2014; Araújo et al., 2018) to identify bioactive compounds derived from cartilage with potential beneficial health properties. However, only one study published by Losso \& Ogawa (2014) has focused on the extraction of collagen from chicken keel bone cartilage and its thermal stability. The present study aimed to optimize the effect of acid pretreatment, temperature and enzyme concentration on the acid-enzymatic extraction of soluble collagen from chicken keel bone cartilage. The study of the optimization of collagen extraction from chicken keel bone cartilage corroborates a technological innovation in the execution of the usual collagen extraction process because this process minimizes operating costs for industry by proposing the use of an extraction temperature of

${ }^{1}$ Programa de Pós-graduação em Ciência e Tecnologia de Alimentos, Departamento de Engenharia de Alimentos, Centro de Tecnologia, Universidade Federal da Paraíba UFPB, João Pessoa, PB, Brasil

${ }^{2}$ Unidade Acadêmica de Engenharia de Alimentos, Centro de Ciência e Tecnologia Agroalimentar, Universidade Federal de Campina Grande - UFCG, Campina Grande, PB, Brasil ${ }^{3}$ Centro de Ciência e Qualidade de Alimentos, Instituto de Tecnologia de Alimentos - ITAL, Campinas, SP, Brasil

*Corresponding author: anarita_k2@hotmail.com 
$30{ }^{\circ} \mathrm{C}$. This study also demonstrates the potential for exploitation of a poultry processing industry by-product, thereby adding value to this activity.

\section{Materials and methods}

\subsection{Materials and reagents}

The pepsin used for the extraction process and the organic acids (acetic, lactic and citric) were supplied by Nuclear (Diadema, São Paulo, Brazil). Other reagents and chemicals used for the analyses were obtained from Sigma-Aldrich Chemie $\mathrm{GmbH}$ (Steinheim, Germany).

Five batches of chicken keel bone cartilages used for this study were made available in a slaughterhouse of the state of Paraíba with Federal Inspection Service of Brazil. Following the cutting sections that involved breast fillet removal, chicken keel bone cartilages were separated from the carcass and collected at random. Then, the cartilages were washed with running water, shredded in a meat processor (CAF Machines, model 5 , São Paulo, Brazil), packed in polyethylene bags and kept frozen $\left(-12^{\circ} \mathrm{C} \leq \mathrm{T} \leq-18^{\circ} \mathrm{C}\right)$ for a period not exceeding 60 days. The samples were used for acid-enzymatic collagen extraction and determination of the chemical compositions and protein profiles (soluble protein, total amino acid profile, peptide hydrophobicity and electrophoretic profile).

\subsection{Production of pepsin-soluble collagen from chicken keel bone cartilage}

Effect of pretreatment with organic acid

The chicken keel bone cartilage was subjected to extraction with organic acids (acetic, lactic and citric) at a $0.5 \mathrm{~mol} / \mathrm{L}$ concentration for different treatment times (24, 48 and 72 hours) at $18{ }^{\circ} \mathrm{C}$ according to a methodology adapted from Liu et al. (2001). Proportions of 1:10 (weight:volume, w/v) of shredded keel and $0.5 \mathrm{~mol} / \mathrm{L}$ of organic acid were homogenized in a Turrax for 10 minutes at $5000 \mathrm{x}$ g, followed by neutralization with a $1 \mathrm{~mol} / \mathrm{L} \mathrm{NaOH}$ solution until a $\mathrm{pH}$ of 7.0 was obtained. Subsequently, the material was centrifuged for 30 minutes at $10,000 \mathrm{x} \mathrm{g}$ at $4{ }^{\circ} \mathrm{C}$. The supernatant was subjected to saline precipitation with $3 \mathrm{~mol} / \mathrm{L}$ of $\mathrm{NaCl}$, followed by centrifugation for 30 minutes at $10,000 \mathrm{xg}$ at $4{ }^{\circ} \mathrm{C}$. The supernatant was discarded, and the precipitate was dialyzed for 72 hours in the same acid solution used at the beginning of the extraction. The solution was changed daily at a ratio of material to be dialyzed to acetic acid solution of 1:50 (w/v). The dialyzed precipitate was lyophilized, and the obtained material (collagen-based isolates) was analyzed to assess the collagen yield, extraction percentage, color and electrophoretic profile parameters.

\section{Optimal conditions for pepsin-soluble collagen extraction}

The chicken keel collagen extraction process conditions were optimized using a $2^{2}$ full factorial experimental design with 4 factor points and 3 central points in a total of seven experiments. The pepsin percentage and enzymatic hydrolysis temperature necessary to obtain the collagen yield (response function) were the independent variables.
The model (Equation 1) adjusted to the experimental data was verified using an analysis of variance (ANOVA) and the determination coefficient $\left(\mathrm{R}^{2}\right)$. The response surface was evaluated using STATISTICA 5.0 (Statsoft Inc. Corporate Tulsa, OK, USA) (StatSoft, 2007).

$y=\beta 0+\beta 1 E+\beta 2 T+\beta 3 E T$

where $\mathrm{y}$ is the response value predicted by the model, $\beta_{0}$ is the mean coefficient (or constant), $\beta 1$ and $\beta 2$ are the linear coefficients, and $\beta 3$ is the interaction coefficient. In this model, $\mathrm{E}$ (pepsin percentage) and $\mathrm{T}$ (equilibrium time) are the independent variables. The dependent variable in this study is the collagen yield.

The proposed model for the optimization of the collagen extraction conditions was validated in triplicate at the conclusion of a new experiment under optimized conditions. The experimental results were compared with the results estimated by the model using the $t$ test $(\mathrm{p} \leq 0.05)$.

\section{Soluble collagen pepsin extraction}

The chicken keel bone cartilage was subjected to extraction with organic acid (the acid used was the one that resulted in the highest collagen yield in the pretreatment step) and the pepsin enzyme according to methodology adapted from Simões et al. (2014). The pre-shredded cartilage was immersed in an acetic acid solution $(0.5 \mathrm{~mol} / \mathrm{L})$ at a $1: 10(\mathrm{w} / \mathrm{v})$ ratio for 24 hours at $18{ }^{\circ} \mathrm{C}$. After that time, the material was homogenized in the Turrax for 10 minutes at $5000 \mathrm{x} \mathrm{g}$. Variable percentages of pepsin at different extraction temperatures were added to the obtained mixture.

To stop the hydrolysis process, the $\mathrm{pH}$ of the mixture was raised to 7.0 with a $1 \mathrm{~mol} / \mathrm{L} \mathrm{NaOH}$ solution; then, this mixture was centrifuged at $10,000 \mathrm{xg}$ for 30 minutes. After discarding the precipitate, the obtained supernatant was precipitated with $\mathrm{NaCl}$ to $3 \mathrm{~mol} / \mathrm{L}$ and again centrifuged at $10,000 \mathrm{xg}$ for 30 minutes. The obtained precipitate was dialyzed for 72 hours in a $0.5 \mathrm{~mol} / \mathrm{L}$ acetic acid solution at a ratio of material to be dialyzed and acetic acid solution of 1:50 (w/v) with a daily exchange of the solution. The dialyzed precipitate was lyophilized, and the obtained material (called the collagen-based isolate) was subjected to a hydroxyproline analysis to determine the collagen yield.

\subsection{Analytical methods}

\section{Partial chemical characterization}

The moisture, ash, protein and collagen analyses were performed following the methodology described in items 950.46A, 920.153, 928.08 and 990.26, respectively, of the AOAC (Association of Official Analytical Chemists, 2010). The lipids were measured according to Folch et al. (1957) procedures.

\section{Determination of soluble protein}

The soluble protein concentration was determined using the Folin-Ciocalteau reagent method with bovine serum albumin as the standard (Lowry et al., 1951). 


\section{Total amino acid profile}

The total amino acids were hydrolyzed, extracted and then derivatized on a pre-column with phenylisothiocyanate (PITC) according to the methodology proposed by White et al. (1986). The phenylthiocarbamyl amino acid derivatives (PTC-aa) were separated on a high efficiency liquid chromatograph (VARIAN, Waters 2690, CA, USA) using a reverse phase C18 column (PICO-TAG, $3.9 \times 150 \mathrm{~mm}$ ). The mobile phases employed consisted of an acetate buffer with pH 6.4 and a $40 \%$ acetonitrile solution. Sample injection was performed manually $(20 \mu \mathrm{L})$, and detection was performed at $254 \mathrm{~nm}$. Chromatographic separation was performed at a constant flow of $1 \mathrm{~mL} / \mathrm{min}$ at $35^{\circ} \mathrm{C}$. The chromatographic run time was 21 minutes, and the results were expressed as a percentage of the area. Amino acids were identified by comparing the chromatograms of the samples with the standards of the analyzed components, and the quantification was performed by the compound area on a calibration curve of each compound. The processing software used was the Galaxie Chromatography Data System.

\section{Electrophoretic profile analysis (SDS-PAGE)}

This technique was performed as described by Laemmli (1970). The stacking gel was prepared at a concentration of $3.5 \%$ polyacrylamide in $0.5 \mathrm{~mol} / \mathrm{L}$ of Tris- $\mathrm{HCl}$ buffer $(\mathrm{pH} \mathrm{6.8)}$ and $1 \%$ SDS, and the separation gel was prepared with a gradient of 7.5 to $17.5 \%$ polyacrylamide in $3 \mathrm{~mol} / \mathrm{L}$ of Tris- $\mathrm{HCl}$ buffer ( $\mathrm{pH} 8.8$ ) and 1\% SDS. The run was performed under a constant amperage of $25 \mathrm{~mA}$. At the end of the run, the gel was removed from the plate, fixed in $12.5 \%$ trichloroacetic acid (TCA) for one hour and then stained with $0.005 \%$ Coomassie brilliant blue R-250. The excess dye was removed using a bleach solution containing methanol, acetic acid and water (1:3.5:8 v/v/v). The molecular weights of the protein fractions were compared using a molecular weight marker (GE Healthcare Life Sciences, Piscataway, NJ, USA).

\section{Collagen yield and collagen extraction percentage}

The collagen yield was obtained by analyzing the amino acid hydroxyproline quantification following the methodology described by (Association of Official Analytical Chemists, 2010). The percentage of collagen extraction relative to the raw material (\%) was expressed as [crude collagen obtained from the chicken keel bone cartilage by organic acid extraction / crude collagen obtained from the chicken keel bone cartilage] x 100 .

\section{Statistical analysis}

The statistical analysis of the acid pretreatment data for the organic acid collagen extraction was performed via a completely randomized design (CRD) using the STATISTICA 8.0 software (StatSoft, 2007). The responses were evaluated using ANOVA at the $5 \%$ significance level, and the treatment means were compared using Tukey's test.

The response function (y) was used to perform the regression analysis and ANOVA. The equation model was adjusted to the experimental data to obtain the proposed model. A response surface graph was generated for the response function (y) (i.e., the collagen yield). The analyses and response surface were performed using the STATISTICA 8.0 software (StatSoft, 2007). After the response surface analysis for the maximum number of extracted collagens, the proposed model was validated by performing new triplicate assays. The results were compared with the estimated response $(\mathrm{Y})$ using Student's t test $(\mathrm{p}<0.05)$.

\section{Results and discussion}

\subsection{Partial chemical composition and amino acid content of the cartilage}

The chicken keel bone cartilage has a high protein content (90.3\%), low lipid content (2.1\%) and was $7.6 \%$ ash on dry basis. A total of $35 \%$ of the proteins were collagen, and $<13 \%$ were quantified as soluble protein. Collagen constitutes about $30 \%$ of the total protein of the animal, being the main structural protein of connective tissue with unique ability to form insoluble fibers, which is why the low content of soluble proteins found in chicken keel cartilage is justified (Liu et al., 2012).

In the amino acid profile, 16 amino acids were identified, of which six were essential. Glycine was the most abundant amino acid, accounting for $22.2 \%$ of the total, followed by alanine (10.2\%), proline (9.5\%), glutamic acid (9.4\%) and hydroxyproline (5.8\%), which were also present in the cartilage. Similar results were reported in the study of Losso \& Ogawa (2014) when determining the amino acid composition of collagen extracted from chicken keel bone cartilage.

We observed that the amino acids hydroxyproline and proline represented $15.3 \%$ of the total amino acids. These amino acids are responsible for conferring the thermal stability of collagen and are fundamental for the formation of the molecule's triple helix. In addition to conferring this stability, hydroxyproline is an indicator of collagen content and is present in a significant amount only in collagen proteins (Thuy et al., 2014; Ricard-Blum, 2011).

The amino acid profile further indicated that $72.97 \%$ of the amino acids found were hydrophobic, and $26.8 \%$ were hydrophilic. Simões et al. (2014) reported that collagen was a molecule consisting of approximately $60 \%$ hydrophobic amino acids and $40 \%$ hydrophilic amino acids; the hydrophobic amino acids are responsible for providing suitable emulsification properties in emulsified products.

\subsection{SDS-PAGE analysis of keel bone cartilage}

The SDS-PAGE patterns of the chicken keel cartilage are shown in Figure 1A. The chicken keel cartilage revealed the existence of two distinct $\alpha$ chains ( $\alpha 1$ and $\alpha 2$ ) at an approximately 2:1 ratio. This result suggests that the collagen is formed by the mixture of types I and II collagen; however, the predominance of the al chain reveals that the collagen is mainly type II with a smaller amount of type I, which can be separated from type II collagen using a new salt precipitation (Losso \& Ogawa, 2014). Type II collagen fibrils correspond to $80 \%$ of the total collagen content and are predominantly and characteristically found in hyaline cartilage (Mendler et al., 1989; Gelse et al., 2003). 


\subsection{Pretreatment with organic acid for the extraction of collagen from chicken keel bone cartilage}

The yield data on the collagen extracted from the chicken keel bone cartilage after pretreatment with different acids for different extraction times are shown in Figure 2. Among the acids used, acetic acid treatment was significantly superior and achieved higher collagen content values.

Acetic acid is the most used acid due to its greater extraction capacity and ability to cause tissue swelling and dissolution of collagenous fibers (Balian \& Bowes, 1977; Gómez-Guillén et al., 2011). Studies have reported the use of acetic acid to obtain acid-soluble collagen from fish by-products, such as mackerel skin and bones (Li et al., 2013), grass carp skin (Liu et al., 2015) and sea bass skin and swim bladder (Sinthusamran et al., 2013).

The best pretreatment was $0.5 \mathrm{~mol} / \mathrm{L}$ of acetic acid over 24 hours because no significant difference was observed for the 48 and 72 hour extraction times. Losso \& Ogawa (2014) reported collagen extraction from chicken cartilage with $0.5 \mathrm{~mol} / \mathrm{L}$ of acetic acid for 72 hours at $4{ }^{\circ} \mathrm{C}$. In another study of collagen extraction
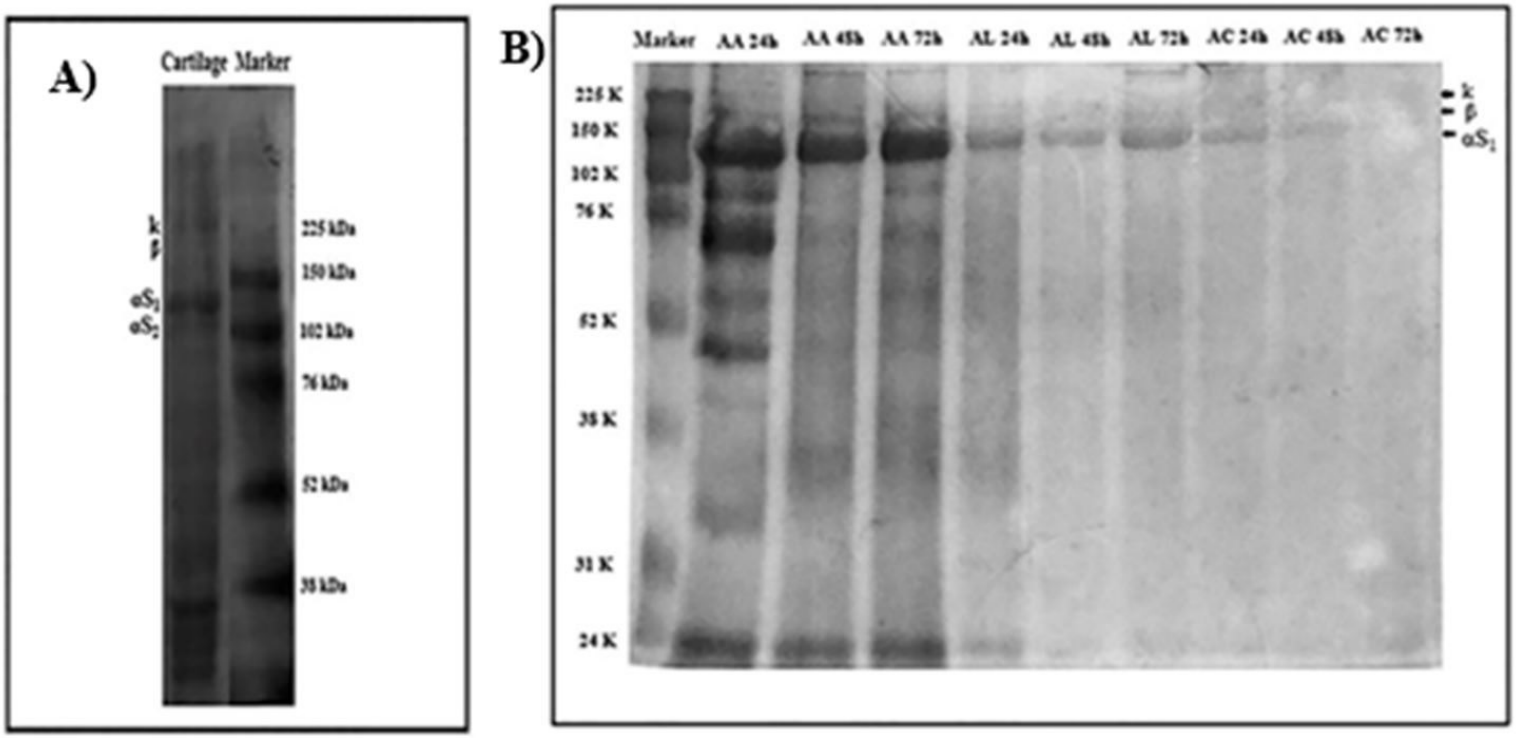

Figure 1. SDS-PAGE patterns of the chicken keel bone cartilage (A) and SDS-PAGE patterns of the collagen extracted from the chicken keel bone cartilage using organic acids (B). AA24h: acetic acid for 24 hours; AA48h: acetic acid for 48 hours; AA72h: acetic acid for 72 hours; AL24h: lactic acid for 24 hours; AL48h: lactic acid for 48 hours; AL72h: lactic acid for 72 hours; AC24h: citric acid for 24 hours; AC48h: citric acid for 48 hours; AC72h: citric acid for 72 hours.

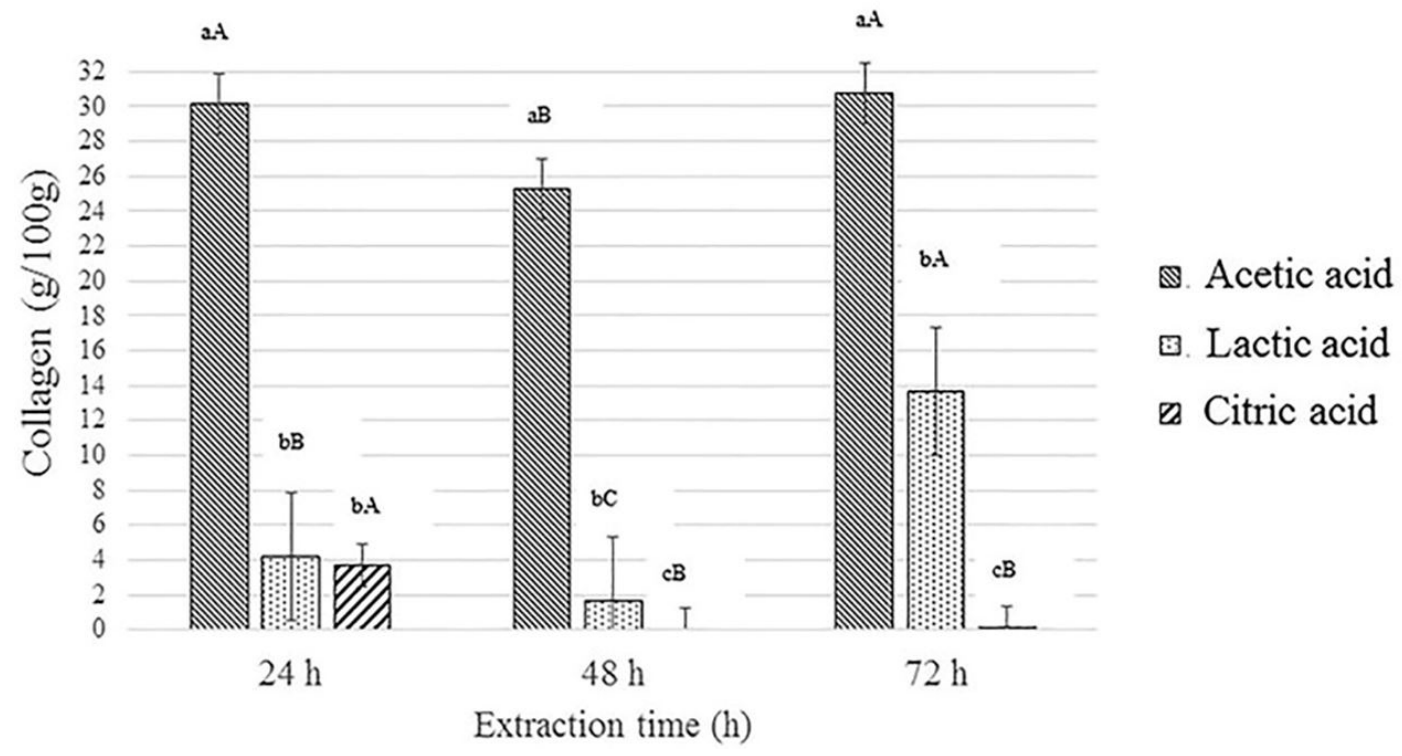

Figure 2. Yield of collagen extracted from the chicken keel bone cartilage treated with $0.5 \mathrm{~mol} / \mathrm{L}$ of different acids and extraction times. ${ }^{\mathrm{a}, \mathrm{b}, \mathrm{c}} \mathrm{Different}$ lowercase letters indicate significant differences $(\mathrm{p}<0.0001)$ between the different acids using the same extraction time. ${ }^{\mathrm{A}, \mathrm{B}, \mathrm{C}} \mathrm{Different}$ upper case letters indicate significant differences $(\mathrm{p}<0.0001)$ between the different extraction times using the same acid. 
from chicken feet, Liu et al. (2001) showed that the treatments that generated the highest collagen yields were $0.5 \mathrm{~mol} / \mathrm{L}$ of acetic acid and lactic acid at $4{ }^{\circ} \mathrm{C}$ with 36 hours of extraction.

The significant difference observed in pretreatment with acetic acid over 48 hours compared to the other two pretreatments might be related to the variation in the $\mathrm{pH}$ of the solution caused by the acetic acid concentration. The $\mathrm{pH}$ affects the ionic interactions and structure, which determine the solubility and extraction of collagen from animal tissues (Cheng et al., 2009b).

The percentages of collagen extraction from the organic acid pretreatments ranged from 71 to $86 \%$ for the samples treated with acetic acid, 4.7 to $38 \%$ for the samples treated with lactic acid and up to $10 \%$ for the citric acid treatments, which confirmed the results found for the yields.

Of the three acids used, pretreatment with citric acid showed a lower efficiency for collagen extraction because this acid was not effective over 48 and 72 hours. Acetic acid and lactic acid were capable of extracting collagen from the chicken keel. This result is similar to the observation of Cheng et al. (2009a) when extracting collagen from chicken feet, in which the greater effectiveness of these same acids was demonstrated.

The electrophoretic profile revealed that the collagens obtained from the organic acid treatments presented protein bands with relative masses ranging from 225 to $24 \mathrm{kDa}$ (Figure 1B) and revealed the existence of predominantly $\alpha 1$ chains. These characteristics were most evident in the acetic acid treatments. The solubility of the proteins after 48 hours may have decreased, and the effect of the solution's $\mathrm{pH}$ may have caused the protein extraction to fail. This result can be observed in the electrophoretic profile after 48 and 72 hours of acetic acid treatment showing an absence or decrease of the lower molecular weight bands.

Protein bands below $150 \mathrm{kDa}$ were not observed for the lactic acid treatments at all extraction times. This result indicates that possible variation in the solution's $\mathrm{pH}$ value decreased the solubility of these proteins (Cheng et al., 2009a). The same finding was observed for the treatments with citric acid where the protein and $\alpha 1$ chain bands were less evident, which confirmed the low ability of citric acid to extract collagen.

The presence of the al chain indicates that the collagen is mainly type II. Type II collagen represents $80 \%$ of the total collagen content and is responsible for the traction and firmness of cartilaginous tissues (Gelse et al., 2003; Losso \& Ogawa, 2014). The molecular weight of the al chain was estimated to be between 100 and $250 \mathrm{kDa}$. This result was similar to the findings of Du et al. (2013), who observed a molecular weight of $134 \mathrm{kDa}$ when studying the functional properties of gelatin extracted from turkey and chicken heads.

\subsection{Optimization of the collagen extraction process using a response surface}

A factorial experimental design $\left(2^{2}\right)$ was used to evaluate the effects of the independent variables $\mathrm{X}_{1}$ (pepsin percentage) and $\mathrm{X}_{2}$ (extraction temperature) on the collagen yield (dependent variable). The results of this design are expressed in Table 1. The Pareto graph (Figure 3A) demonstrates the importance of the studied variables and their interactions. The enzyme percentage and extraction temperature are important variables for optimized collagen extraction because their combination can generate a greater or lesser collagen yield.

The determination coefficient $R^{2}$ was 0.91775 . This high value revealed that the response function adequately adapted to the data and that this model could be used to predict collagen extraction from chicken keel bone cartilage. The ANOVA showed that the proposed model was significant. According to the F test, there was significant regression, because Fcalculated $>$ Ftabulated and did not present a lack of adjustment (Fcalculated $<$ Ftabulated). Considering the variables and significant interactions, we obtained Equation 2 for the proposed model, which was expressed as

$Y=66.35+3.38 X_{1}-1.07 X_{2}-0.82$

where $\mathrm{Y}$ (collagen yield) is the response value predicted by the model and $\mathrm{X}_{1}$ (percentage of pepsin) and $\mathrm{X}_{2}$ (collagen extraction temperature) are the independent variables.

The Pareto chart (Figure 3A) shows that the extraction temperature and the interaction between $\mathrm{X}_{1}$ and $\mathrm{X}_{2}$ are not significant. The only significant effect was caused by the variation in the pepsin percentage. After analyzing these data, we obtained

Table 1. Factorial design $\left(2^{2}\right)$ with independent variables, treatments and experimental responses $(\mathrm{Y}=$ collagen yield $)$ for the chicken keel bone cartilage collagen extraction process.

\begin{tabular}{|c|c|c|c|}
\hline \multirow[b]{2}{*}{ Treatment } & \multicolumn{2}{|c|}{ Independent variables and variation levels $\left(\mathrm{X}_{1}\right.$ and $\left.\mathrm{X}_{2}\right)$} & \multirow{2}{*}{$\begin{array}{c}\text { Response function }(\mathrm{Y}) \\
\text { Collagen yield } \\
\text { (g/100 g of collagen) }\end{array}$} \\
\hline & $\begin{array}{l}\text { Pepsin } \\
(\%)\end{array}$ & $\begin{array}{c}\text { Extraction temperature } \\
\left({ }^{\circ} \mathrm{C}\right)\end{array}$ & \\
\hline 1 & $(-1) 0.1$ & $(-1) 4$ & 61.72 \\
\hline 3 & $(-1) 0.1$ & $(+1) 30$ & 61.80 \\
\hline 4 & $(+1) 1.0$ & $(+1) 30$ & 66.05 \\
\hline 7 & (0) 0.55 & (0) 17 & 62.96 \\
\hline \multicolumn{3}{|c|}{ Raw material ( $\mathrm{g}$ of collagen $/ 100 \mathrm{~g}$ of cartilage) } & 35.69 \\
\hline
\end{tabular}

Coded and real values for experimental planning. 


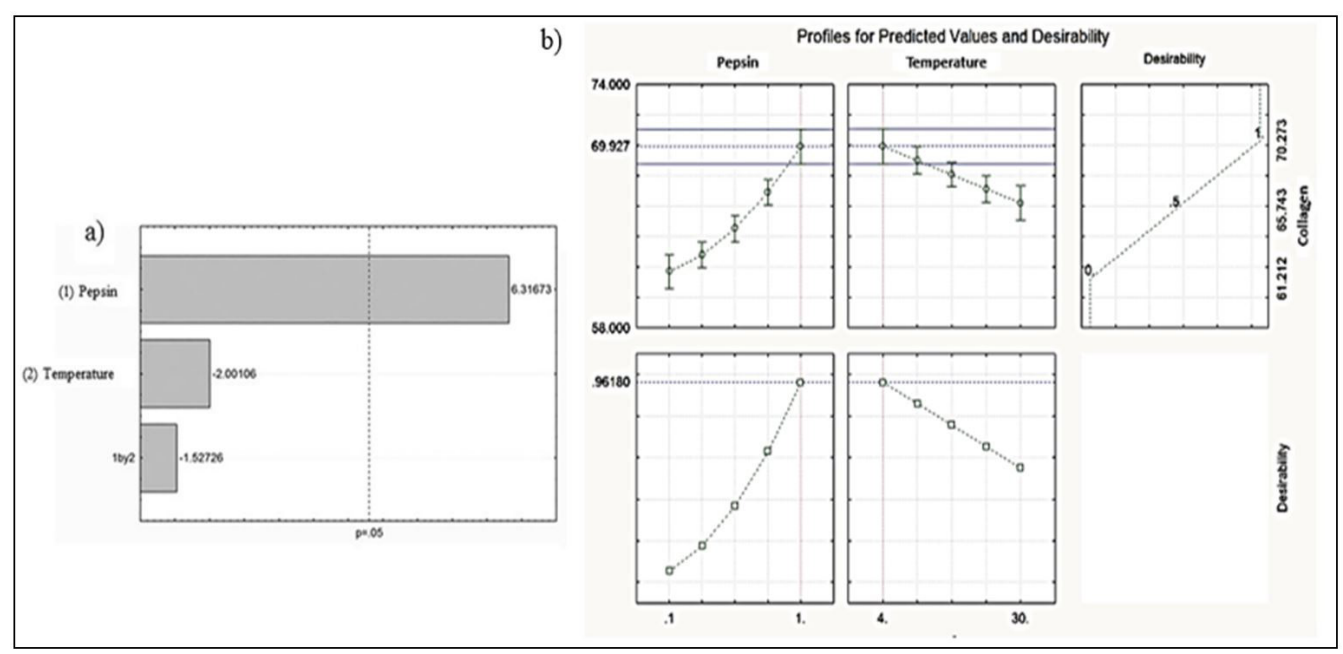

Figure 3. Pareto Chart (a) of the dependent variable "collagen yield". (1) Pepsin: Percentage of the pepsin enzyme; (2) Temperature: Collagen extraction temperature; 1by2: Interaction between the pepsin percentage and extraction temperature parameters. Desirability graph (b) of the collagen yield. Temperature: Extraction temperature; Pepsin: Percentage of pepsin used.

a desirability graph (Figure 3B) that indicates the optimal region, taking into account all the variables at the same time.

The desirability function was applied in this study (Figure 3B) to confirm the values selected for the optimized variables (temperature and percentage of the pepsin enzyme) indicated by the response surface. As indicated by the desirability function, the ranges of the temperature and pepsina were $4{ }^{\circ} \mathrm{C}$ to $30{ }^{\circ} \mathrm{C}$ and $0.1 \%$ to $1 \%$, respectively. Based on these results, the values of $1 \%$ of pepsin and $4{ }^{\circ} \mathrm{C}$ of hydrolysis time (corresponding to experiment 2 of the applied Full Factorial Plan) were considered optimal. This result confirms that this variable has a significant effect on collagen extraction with the use of a higher pepsin content. Because the temperature variable demonstrated no effect on the final yield, we chose the temperature that represented the lowest process cost (i.e., $30^{\circ} \mathrm{C}$ ).

The use of pepsin and acetic acid for collagen extraction has been described in other studies, particularly to characterize the collagen from various types of tissue. Seeking to identify the collagen types present in mechanically separated chicken meat, Tanaka \& Shimokomaki (1996) used pepsin and acetic acid $(0.5 \mathrm{~mol} / \mathrm{L})$ over 24 hours for extraction and obtained a yield

of $8.3 \%$ of collagen on a dry basis (d.b.); these authors also identified the presence of types I, II, III and V collagen. Additionally, many studies have shown that acid extraction and pepsin hydrolysis both increase the yield. Losso \& Ogawa (2014) observed that collagen extraction with $0.5 \mathrm{~mol} / \mathrm{L}$ of acetic acid followed by hydrolysis with $0.1 \%$ pepsin at $4{ }^{\circ} \mathrm{C}$ (pepsin-soluble collagen) produced a higher yield than extraction with acid alone (acid-soluble collagen).

According to Losso \& Ogawa (2014), collagen extracted from chicken keel bone cartilage has high thermal stability and the highest denaturation temperature among the collagen of all vertebrates. Therefore, the chosen temperature variation did not affect the collagen extraction.

\subsection{Model validation}

Based on the $\mathrm{Y}$ response function (collagen yield) and the proposed process optimization model, the estimated values of $\mathrm{X}_{1}=1 \%$ and $\mathrm{X}_{2}=30^{\circ} \mathrm{C}$ should be used to obtain pepsin-soluble collagen at a yield of $66.05 \mathrm{~g}$ collagen per $100 \mathrm{~g}$ of collagen. The optimal point was reproduced in triplicate to yield a response of $66.85 \mathrm{~g}$ of collagen per $100 \mathrm{~g}$ of collagen. When analyzed by ANOVA and subjected to the $t$ test $(\mathrm{p}<0.05)$, neither the experimental nor the predicted mean differed significantly, indicating that the proposed model was adjusted to the experimental data.

\section{Conclusion}

This study investigated the chemical and protein characterizations of chicken keel bone cartilage and revealed that the collagen contained a high protein content ( $>90 \%$ d.b.). Therefore, chicken keel bone cartilage is an important source of collagen ( $36 \%$ d.b.) and essential amino acids. The use of $0.5 \mathrm{~mol} / \mathrm{L}$ of acetic acid for a period of only 24 hours was the best pretreatment option for collagen extraction because this procedure reduced the extraction time and total process cost.

The optimal conditions for extracting collagen from chicken keel bone cartilage were obtained using $1 \%$ of the pepsin enzyme at an extraction temperature of $30^{\circ} \mathrm{C}$. Optimization was confirmed by validation of the method, which obtained a collagen yield of $66.85 \%$. This yield was higher than the yield obtained from other chicken slaughter by-products, such as feet, comb and wattle.

\section{Acknowledgements}

The authors thank the Conselho Nacional de Desenvolvimento Científico e Tecnológico (National Council for Scientific and Technological Development; CNPq) and the Programa Professor Visitante do Exterior (Foreign Visiting Professor Program; PVE) for their financial support and the scholarship granted to the first author. 


\section{References}

Araújo, Í. B. S., Bezerra, T. K. A., Nascimento, E. S., Gadelha, C. A. A., Santi-Gadelha, T., \& Madruga, M. S. (2018). Optimal conditions for obtaining collagen from chicken feet and its characterization. Food Science and Technology (Campinas), 16(suppl 1), 1-7. http:// dx.doi.org/10.1590/fst.27517.

Association of Official Analytical Chemists - AOAC. (2010). Official methods of analysis of association of official analytical chemists (18th ed.). Maryland: AOAC.

Balian, G., \& Bowes, J. H. (1977). The structure and properties of collagen. In A. G. Ward, \& A. Courts (Eds.), The science and technology of gelatin (pp. 1-30). London: Academic Press.

Cheng, F., Hsu, F., Chang, H., Lin, L., \& Sakata, R. (2009a). Effect of different acids on the extraction of pepsin-solubilised collagen containing melanin from silky fowl feet. Food Chemistry, 113(2), 563-567. http://dx.doi.org/10.1016/j.foodchem.2008.08.043.

Cheng, F., Wan, T., Liu, Y., Chen, C., Lin, L., \& Sakata, R. (2009b). Determination of angiotensin-I converting enzyme inhibitory peptides in chicken leg bone protein hydrolysate with alcalase. Animal Science Journal, 80(1), 91-97. http://dx.doi.org/10.1111/j.17400929.2008.00601.x. PMid:20163474.

Du, L., Khiari, Z., Pietrasik, Z., \& Betti, M. (2013). Physicochemical and functional properties of gelatins extracted from turkey and chicken heads. Poultry Science, 92(9), 2463-2474. http://dx.doi.org/10.3382/ ps.2013-03161. PMid:23960131.

Folch, J., Lees, M., \& Stanley, S. G. H. (1957). A simple method for the isolation and purification of total lipids from animal tissues. The Journal of Biological Chemistry, 226(1), 497-509. PMid:13428781.

Gelse, K., Poschl, E., \& Aigner, T. (2003). Collagens - structure, function and biosynthesis. Advanced Drug Delivery Reviews, 55(12), 15311546. http://dx.doi.org/10.1016/j.addr.2003.08.002. PMid:14623400.

Gómez-Guillén, M. C., Giménez, B., López-Caballero, M. E., \& Montero, M. P. (2011). Functional and bioactive properties of collagen and gelatin from alternative sources: a review. Food Hydrocolloids, 25(8), 1813-1827. http://dx.doi.org/10.1016/j.foodhyd.2011.02.007.

Laemmli, U. K. (1970). Cleavage of structural proteins during the assembly of the head of bacteriophage T4. Nature, 227(5259), 680685. http://dx.doi.org/10.1038/227680a0. PMid:5432063.

Lafarga, T., \& Hayes, M. (2014). Bioactive peptides from meat muscle and by-products: generation, functionality and application as functional ingredients. Meat Science, 98(2), 227-239. http://dx.doi. org/10.1016/j.meatsci.2014.05.036. PMid:24971811.

Li, Z.-R., Wang, B., Chi, C., Zhang, Q.-H., Gong, Y., Tang, J.-J., Luo, H., \& Ding, G. (2013). Isolation and characterization of acid soluble collagens and pepsin soluble collagens from the skin and bone of Spanish mackerel (Scomberomorous Niphonius). Food Hydrocolloids, 31(1), 103-113. http://dx.doi.org/10.1016/j.foodhyd.2012.10.001.

Liu, D. C., Lin, Y. K., \& Chen, M. T. (2001). Optimum condition of extracting collagen from chicken feet and its characteristics. AsianAustralasian Journal of Animal Sciences, 14(11), 1638-1644. http:// dx.doi.org/10.5713/ajas.2001.1638.

Liu, D., Liang, L., Regenstein, J., \& Zhou, P. (2012). Extraction and characterisation of pepsin-solubilised collagen from fins, scales, skins, bones and swim bladders of bighead carp (Hypophthalmichthysnobilis). Food Chemistry, 133(4), 1441-1448. http://dx.doi.org/10.1016/j. foodchem.2012.02.032.

Liu, D., Wei, G., Li, T., Hu, J., Lu, N., Regenstein, J. M., \& Zhou, P. (2015). Effects of alkaline pretreatments and acid extraction conditions on the acid-soluble collagen from grass carp (Ctenopharyngodon idella) skin. Food Chemistry, 172, 836-843. http://dx.doi.org/10.1016/j. foodchem.2014.09.147. PMid:25442628.

Losso, J. N., \& Ogawa, M. (2014). Thermal stability of chicken keel bone collagen. Journal of Food Biochemistry, 38(3), 345-351. http:// dx.doi.org/10.1111/jfbc.12059.

Lowry, O. H., Rosebrough, N. J., Farr, A. L., \& Randall, R. J. (1951). Protein measurement with the folin phenol reagent. The Journal of Biological Chemistry, 193(1), 265-275. PMid:14907713.

Mendler, M., Eich-Bender, S. G., Vaughan, L., Winterhalter, K. H., \& Bruckner, P. (1989). Cartilage contains mixed fibrils of collagen types II, IX and XI. The Journal of Cell Biology, 108(1), 191-197. http:// dx.doi.org/10.1083/jcb.108.1.191. PMid:2463256.

Ricard-Blum, S. (2011). The collagen family. Cold Spring Harbor Perspectives in Biology, 3(1):a004978. http://dx.doi.org/10.1101/ cshperspect.a004978.

Simões, G. S., Silveira, E. T. F., Oliveira, S. R., Poleze, E., Allison, J. R. D., Ida, E. I., \& Shimokomaki, M. (2014). Optimum conditions for extracting collagen from the tunica albuginea of immunologically castrated pig testes and the functional properties of the isolated collagen. Meat Science, 96(4), 1460-1468. http://dx.doi.org/10.1016/j. meatsci.2013.10.038. PMid:24412738.

Sinthusamran, S., Benjakul, S., \& Kishimura, H. (2013). Comparative study on molecular characteristics of acid soluble collagens from skin and swim bladder of seabass (Lates calcarifer). Food Chemistry, 138(4), 2435-2441. http://dx.doi.org/10.1016/j.foodchem.2012.11.136. PMid:23497906.

StatSoft. (2007). Statistica for windows software (Vol. 8.0). Tulsa: Statsoft Inc.

Tanaka, M. C. Y., \& Shimokomaki, M. (1996). Collagen types in mechanically deboned chicken meat. Journal of Food Biochemistry, 20(1), 215-225. http://dx.doi.org/10.1111/j.1745-4514.1996.tb00552.x.

Thuy, L. T. M., Okasaki, E., \& Osako, K. (2014). Isolation and characterization of acid-soluble collagen from the scales of marine fishes from Japan and Vietnam. Food Chemistry, 149, 264-270. http://dx.doi.org/10.1016/j.foodchem.2013.10.094. PMid:24295705.

Toldrá, F., Aristoy, M. C., Mora, L., \& Reig, M. (2012). Innovations in value-addition of edible meat by-products. Meat Science, 92(3), 290 296. http://dx.doi.org/10.1016/j.meatsci.2012.04.004. PMid:22560456.

Wang, S., Sun, X., \& Zhou, D. (2017). Physicochemical characteristics and fibril-forming properties of collagen from paddlefish (Polyodon spathula) and globefish (Fugu flavidus) skin byproducts. Food Science and Technology (Campinas), 37(2), 176-183. http://dx.doi. org/10.1590/1678-457x.15416.

White, J. A., Hart, R. J., \& Fry, J. C. (1986). An evaluation of the Waters Pico-Tag system for the amino-acid analysis of food materials. Journal of Automatic Chemistry, 8(4), 170-177. http://dx.doi.org/10.1155/ S1463924686000330. PMid:18925132. 